\title{
JOHANN AUGUST LUDWIG PREISS (1811-1883) IN WESTERN AUSTRALIA
}

\author{
D.J. McGillivray \\ (Received June 1974)
}

\section{ABSTRACT}

McGillivray, D. J. (National Herbarium of New South Wales, Royal Botanic Gardens, Sydney, Australia) 1975. Johann August Ludwig Preiss (1811-1883) in Western Australia. Telopea $I$ (1): 1-18. A short account is given of Preiss's stay in Western Australia from 1838 to 1842 , based mainly on letters written by Preiss and his contemporaries during that period. Some glimpses of his personality are seen and his association with James Drummond (1784-1863) is briefly mentioned. Preiss's estimate of the quantities of his various collections is reprinted (p, 8). Letters are reproduced relating to the purchase of a set of Preiss's botanical collections now housed in the herbarium of Trinity College, Dublin (TCD). A sample of Preiss's handwriting (p. 10) may assist zoologists as well as botanists in assigning specimens to his collections. Herbaria known to contain specimens from Preiss are listed (p. 8). Tables are given showing the publication dates and a summary of the contents of Plantae Preissianae (ed. J.G.C. Lehmann) 18441848 (pp. 12-15). Some further data about his collections are provided in letters from Preiss to William Hooker and to Robert Brown. The author would be pleased to learn from anyone who knows the present location for Preiss's plant specimens Nos. 2621-2644, many being types which have not been seen in recent years.

Johann August Ludwig Preiss was born in Herzberg am Harz near Göttingen on 21 November 1811.

In a paper on Lehmann's Plantae Preissianae, Stearn (1939) 204-205 provides the following information about Preiss's years in Germany:-

"That he received a university education is shown by his degree of Dr. phil. In August 1843, when he was a "Privat-gelehrter in Hamburg", i.e. a scholar not on the staff of an institution, he became a member of the Academia Caesarea Leopoldino-Carolina Naturae Curiosorum at Halle under the cognomen of "Cunningham" (cf. J.D.F. Niegebaur, 1860, Gesch. K. Leop.-Carol. deutsch Akad. während 2ter Jahrhund.: 270). He died on 21 May 1883 at Herzberg am Harz (cf. W. Ule, 1889, Gesch. K. Leop.-Carol. deutsch. Akad. während 1852-1887: 182), where he had settled in 1844."

The most recent biographical note on Preiss [Calaby (1967)] provides no further information about these years.

Preiss arrived in Fremantle, Western Australia, on 4th December 1838, shortly after his 27th birthday, and during the following three years worked enthusiastically and carefully to amass a fine botanical collection which together with those made by James Drummond (1784-1863), forms the basis for early taxonomic studies on the flora of that State.

A general summary of his collecting itinerary is given by Diels (1906) 47 [translation]:

"Preiss dedicated the entire first year to collecting in the vicinity of the Swan River, as well as collecting the littoral flora near Fremantle and (in the company of Drummond) on Rottnest Island. In the Perth district he collected widely, going as far east as the foothills of the Darling Range. It was not until September 1839 that he climbed the plateau and explored the forests on either side of the highway, which he followed as far as York. He soon returned, however, and in November and December of the same year he visited the area around Geographe Bay, penetrating as far as the present-day town of Busselton. In March of the next year he crossed the Darling Range again, travelling as far as the Avon Valley. Here he prepared for an important journey into the 
Victoria District to the north of Perth, travelling as far as the Quangan Plains. IThe Quangan or Guangan Plains is the area to the north and north-east of Toodyay which is about $100 \mathrm{~km}$ north-east of Perth. The name, rarely used today, was applied by Drummond to the sandheaths between Toodyay and the Wongan Hills. A.S. George, pers. comm. 1973]. This journey occurred in the most unfavourable time of the year, so that obviously only a minimal portion of the rich flora of that area was actually in flower. Nonetheless Preiss made some of his best discoveries there.

During the first month of the rainy season of 1840 Preiss appears to have collected little. In August he prepared for his departure southwards; this trip kept him away from the Swan River for about half a year. From September onwards, until February of 1841, his headquarters were in Albany. He collected very thoroughly in the vicinity of this town, an area which was comparatively better known. However, he still made excursions into quite unknown areas: one along the newly-opened mail road north-west into the Gordon River area $\left[\right.$ c. $34^{\circ} 15^{\prime}$ S., $117^{\circ} 18^{\prime}$ E.]; another, in November 1840 , to Cape Riche, where he discovered a particularly large number of novelties. At the end of the dry season we find him back at the Swan River, where he spent a few more months collecting, apparently with a view to enlarging his collection of dried specimens of cryptogams."

Some of Preiss's contemporaries in Western Australia, James Drummond (more than 25 years his senior), Mrs Georgina Molloy and Mr G.F. Moore provide a little information and insights into Preiss and his collections.

From the diary of G.F. Moore (1884) 382 in May 1839:-

"Mr. Preiss, the naturalist, has called a species of anigozanthus after me, and has sent me a droll letter with it, written in his German-English. He has also called a new genus after the Governor-"Huttia elegans". These are to be figured in the work of Sir F. [sic] Hooker, of Glasgow."

This letter, aptly described by Moore, is contained in W.J. Hooker's correspondence at Kew.

Dear Sir

"Perth 7. May 1839.

Having looked over my Collection of Plants I found amongst many new ones a plant to which I paid a particular attention. I thought, well, this plant must be baptized at the spot and therefore I began to work. I did baptize with hot water and what venerable Christian-name it has got you will hear instantly.

Being well known in this Colony and also on the Continent of Europe partly, what many immortal merits you have deserved for the welfare of this Colony in every respect I am not able in finding out an other way to put an everlasting Monument to You in the learned world as in taking the liberty to dedicate this magnificent plant to You.

As soon as an opportunity should appear You or myself may send this plant with description (I shall supply You with an other one) to Sir W. J. Hooker, Professor of Botany at the University of Glasgow, with the request, that he might figure it in his famous Botanical Miscellanies

P.S. If I should not have properly expressed myself, pray to consider that I am not yet well acquainted with your Mother language." [Preiss to Moore, Hooker Correspondence Vol. 50].

Apparently such an opportunity was not sought, for Hooker's correspondence contains no letters from Preiss prior to 1843; neither did Hooker act on the material received from Moore.

Moore op. cit. p. 387 of 26 July 1839:-

"This morning Mr. Preiss, the German naturalist, came here, and Mr. Irwin. We all set out on an excursion to the hills to botanise. We visited a very picturesque glen about five miles away [in the Darling Ranges] where there is a waterfall about 100 feet high, but there was not much water in it. The locality was rich in specimens of plants and flowers. . .

July 27 th.-Mr. Preiss the botanist, was out to-day in the hills behind this, and he came here for dinner, laden with specimens, and having a native woman also carrying another load of specimens. The natives are quite surprised at his collecting the jilbah (shrubs), and are very curious to know what he does with them . . .".

In November 1839 Mrs Georgina Molloy, a lady who received considerable pleasure from the study and cultivation of native flowers, invited Preiss to 
'Fair Lawn', the home of Captain and Mrs Molloy, on the Vasse River (west of the town of Busselton). Preiss's visit was the main topic of her letter of 31 January 1840 to her friend Captain Mangles, a retired naval officer interested in natural history and horticulture, who came to the Swan River Colony in 1831.

"The present Governor [Hutt] paid us a visit in November. From him I heard of a Gentleman of the name of Preiss, a German, and one employed by the Austrian and Russian Governments to collect the natural productions of this Country. He is really a Botanist. I thought he might aid me in information respecting the plants of this country, and at the same time benefit himself . . . I accordingly invited him to 'Fair Lawn' and he staid with us about a month [December 1839]; being so pleased with the Country and its many new Floral productions. He has resolved upon visiting us again. When here he collected many Specimens, and of course tendered me some of his labour, but so rough and ungainly were many, I could not deface the Hortus Siccuses with them, so had recourse to fixing them on stiff paper." [Extracted from Hasluck (1955)].

For the purposes of botanical study Preiss's specimens are usually wellselected and properly pressed, frequently being superior in quality to those collected by Drummond. Such collections would not be expected to meet the criteria in form and presentation demanded by a lady for her hortus siccus. Preiss's collections are further enhanced by precise collection data including locality, date of collection (day, month, and year), habit and habitat.

Preiss had also stayed at Mrs Bull's place at Picton, on Leschenault Inlet, near Bunbury, on his way to the Molloy's.

Mrs Molloy remembered Preiss for his failure to write and to send specimens as he had promised. In a letter to Captain Mangles she remarked in March 1840:-

"He was here at a bad time but is coming down in the Spring. He promised to write and send me particulars respecting seeds etc. but we have heard nothing of him, although he had excellent opportunities. You would be surprised to see how easily persons in this colony lay aside the common rules of Society." [Hasluck (1955) 196].

And again on 4 June 1841:-

... When Mr. Preiss was here, for the use of my preservative soap he promised me many stuffed Birds, but none has as yet arrived. He is still in the Colony surveying on the Canning, I believe ...

Diels (1906) 52 provides a picture of the contrasting natures of Preiss and Drummond:-

"Ein sonderbarer Zufall hat die gründlichsten Leistungen zur floristischen Erforschung des Landes im letzten Jahrhundert zeitlich so nahe zusammenfallen lassen, dass DRUMMOND und PREISS sich begegneten und Tage gemeinschaftlicher Tätigkeit verleben durften. Und diese Fügung konnte sich um so folgenreicher gestalten, als in jenen beiden Männern vollendete Gegensätze verkörpert waren: PREISS ein im alten Europa gut geschulter Gelehrter, stets darauf bedacht, das Chaos des oberflächlich Bekannten $\mathrm{zu}$ klären und $\mathrm{zu}$ sichten; selten dazu aufgelegt, neues Gelände zu erobern, aber jede Pflanze seiner Sammlung nach Standort und Datum sorgfältig verzeichnend, wie es niemand vorher in West-Australien gethan; DRUMMOND dagegen der echte "Bushman", stets im Sattel, am liebsten auf ungebahnten Pfaden in der Wildnis, vor allem Neues suchend, von jeder neuen Art beglückt, mit scharfem Blick für Unterscheidung begabt, aber nach allem sonst erst in zweiter Linie fragend: der echte Sammler, aber kein solcher, der gern registriert oder Ordnung hält."

[Translation] By a strange coincidence, the two most significant original contributions to the investigation of the state's flora during the last century occurred so close together that it was possible for Drummond and Preiss to spend days together collecting. This association was all the more productive since the two men embodied completely opposite traits. Preiss was the intellectual, well-educated in old Europe, always endeavouring to resolve and refine the chaos of superficial knowledge, but seldom inclined to explore new country; carefully labelling each plant in his collection with locality and date, as no one 
had done before in Western Australia. Drummond on the other hand was the true bushman, always in the saddle and happiest travelling untrodden paths out in the open spaces, always looking for something new, delighted with each new species, gifted with a sharp eye for differences but not very concerned with looking for reasons: a true collector but not one who liked to record and arrange his specimens.

Erickson (1969) 44 et seq. adds considerably to the information about Preiss and Drummond and the 'innate rivalry that set them at loggerheads on some questions'. [Mrs Erickson's lively, sympathetic and well-documented study is an excellent source of information about the Drummond family and its contemporaries.]

Drummond was concerned that Preiss's collections would be available to Continental botanists before British botanists had the same opportunities to study and describe the flora of the Swan River Colony. Preiss was more financially independent than Drummond, and freer to devote his energy to collecting and preserving specimens. An issue over which Preiss and Drummond conflicted most deeply concerned plants poisonous to stock. See Erickson (1969) 53-60 for a detailed account.

"Drummond was convinced at last of the identity of the dangerous plant (now known as York Road Poison Gastrolobium calycinum) ... Preiss continued to claim that the plant was not poisonous, but blamed the combined effects of its woody nature, the hairy seed pod, and the prickly leaves for causing an acute irritation in the animals' stomachs.

To prove his point he drank, with bravado, a wineglass full of an infusion of the leaves." [Erickson (1969) 58-59].

Gardner \& Bennetts (1956) 79 refer to this species: “. . . when taken naturally [by sheep], the more highly toxic species like York Road Poison tend to give rise to delirium and madness ...."

Preiss, having suffered no ill effects from the infusion, recommended the plant to members of the Agricultural Society for cultivation as a stock fodder.

Apparently Preiss had claimed that not only was this non-injurious to stock, but that there were no poisonous plants native to the colony. Feeding trials made in May 1841 proved beyond any doubt that at least some of the colony's leguminous plants were poisonous to stock.

"Preiss was placed in an invidious position by his stand on the poison question and his prestige waned. He continued to botanise extensively but was not so welcome at homesteads as formerly. His lack of courtesy was noted by Mrs. Molloy. After enjoying her hospitality at 'Fair' Lawn' for a month, in December 1840 [actually 1839] he had not communicated with her again, nor sent her certain specimens which he had promised. He suffered frustration when the British Government ignored his offer to sell his collection to them, and his naturalisation was not approved by Act of Council until 15th April 1841.

Preiss began making arrangements to leave the colony. He hoped to make an early departure by sailing by way of Singapore but was obliged to wait until the end of the year when the woolboats called again."

[Erickson (1969) 60].

In October 1839 when Preiss had already gathered some 1500 species of plants he offered his entire collection to the British Government. His letter of 11 October to Governor Hutt provides a little biographical data and gives some understanding of his foresight, his devotion to the science of natural history and his consideration for the colony to which he had come. With the letter he provided a catalogue of his collections "and two sets of botanical specimens which were forwarded to England with the letter". [Erickson (1969) 45]. The letter, with Preiss's minor spelling errors is quoted here: 
"Perth, Western Australia. Octbr, 11.1839 .

$\operatorname{Sir}$

I beg leave to submit to your Excellency's kind judgement an object of great importance to myself.

How often circumstances and newly formed projects may be thrown out of their intended track of this the following facts offer an evident proof.

The purpose of my presence on this very unknown part of the world as relates to Natural History, is to collect the products of it and arrange those products in a usefull way for the purposes of Science. For this I have been sent here and may remain as long as I think proper.

[The same scientific spirit, but this time tempered by impecunity, is reiterated in one of his letters to W.J. Hooker in June 1842:-

My chief intention is to bring the objects of my various collections in possession of all Botanists and Naturalists by putting a price on them they are content with; how-ever I wish, at the same time, to recover my own expenses.]

My intention since my arrival at this place was always to return in 2 or 3 years to Germany and to give lectures upon Natural History because I saw it to be impossible to prosecute my travels with the allowance that [was] made me [so] as to undertake distant excursions into the Interior with attendants and other necessary conveniences.

But in the course of my excursions in this Country I have often been so struck with the fine character of it for Agriculture that it has caused in me the desire to settle myself here as soon as possible provided I could dispose of my Collections of Natural objects made in this Country which beyond my exspectation have increased rapidly both in variety and rarity. The climate which agrees well to my constitution has contributed a great deal to the determination, and I am cheered with the pleasant hopes that if quitly settled, I would be able to spend my Days both in agriculture and in the elaboration of the extensive field of Natural History of the Country.

Your Excellency can judge best of my Collections because I have often had the honour to show You them.

I could but think that the British Government has certain right to have them first offered as being the produce of a British territory. The catalogue of my Collections I took liberty some days ago to send to Your Excellency by the kindness of Mr. Cowan, and I now enclose some specimens of my dried plants as a sample for the British Government.

I flatter myself I may state that such a Collection has never been sent from this Country to England amongst them are many new objects not known in any Museum of Great Britain or any others on the Continent of Europe, particularly of the Insects. I make myself responsible for all I say.

I do not think that the sum of $£ 3,000$ will be considered an exorbitant price, if I state that those collections will cost me till Decbr. 1840, including my expenses out more than $f 800$, and I may propose to the British Government to allow me the Sum of $£ 2,000$ in ready money with a tract of Land for $£ 1000$ at the minimum price of $5 /$ per Acre.

Should the British Government accept this offer I intend to return home for one year, and would again bring out with myself besides my two brothers, 50 young Families of healthy condition from Saxony and the Rhine-Provinces (persons having knowlledge of sheepfarming and cultivation of Wine) of whom I would keep some and the other ones give to other Settlers on repayment of my advanced money for Passage etc. In what way it would be best to engage such people I would take liberty to request before my departure the kind opinion of Your Excellency and would in accordance perfectly act to it. In this case I might ask Your Excellency whether $I$ can lay any claim to that British law for Colonies that he who brings Families to this Country would get per each one 20 Acres as gratification [gratuity]. On arriving on the Continent of Europe, I should find it by all means necessary to make this emigration to Western Australia known by advertissements in several News-papers-to travel myself to Saxony and the Rhine-Provinces to speak about this with the Magistrates (or Burgermeister), and all this will cause expenses for my part. It is not at all my intention to have by this any advantage, but, because I feel so great a prepossession for this Colony.

Before I should send my collections home, I would select a quite complete one of all objects for the future Museum of this Colony and I would continue to make collections gratis for the British Government.

Finally I beg leave to state, that, if the British Government should decline my proposal I intend to go to the North-Coast of this Country and shall therefore submit to the Prussian and Russian Governments a petition for doubling my allowance for one year and a half.

Begging to excuse my great liberty, I have the honour to be Your Excellency's

most humble and obedient Servant

L. Preiss." 
The itemized account of his collections reads as follows:-

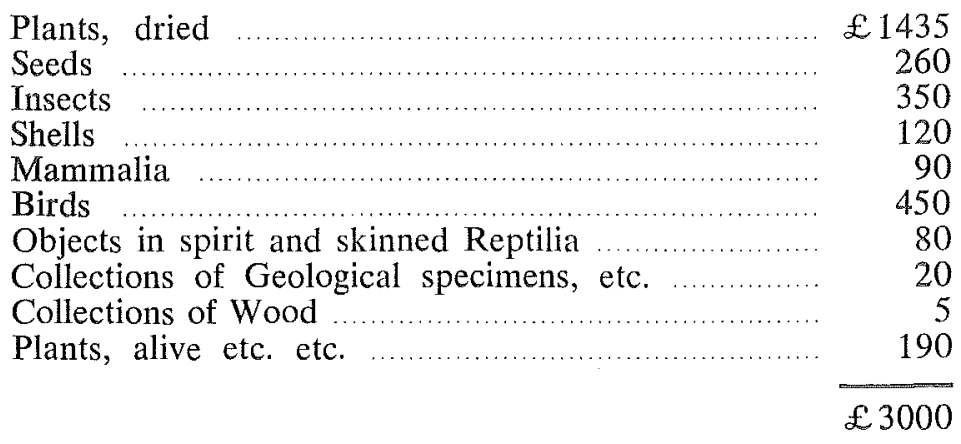

The catalogue accompanying the letter does not give the names of plants, since these were available from the sets of specimens provided at the same time. However it does contain Preiss's assessment of the quality of the specimens and details of the sorts of data he tried to record for each collection. The first portion of the catalogue referring to plants and seeds, and the concluding remarks are reproduced here, preceded by my summary of the remaining contents.

\section{SUMMARY}

Insects in general: about 700 species which "may consist of about 15,000 specimens".

Spiders: ". . more than 20 species generally with their nests . . ".

Shells: about 150 species; 34 genera are listed, some with epithets, others with a note of the number of species.

Mammalia: 20 species with several specimens of each, and notes on eye colour, food preferences, habitat, etc.

Birds: 162 species with notes on colour, food preferences, voice, abundance, "nest and eggs but not of every bird-and preserved the tongue". [See Meise, W. (1951)].

Various "zoophytes" and crustacea.

Fishes: at least 30 species.

Crabs: 6 species.

Iguanae and Lizards: about 20 species.

"Minerals and Geological Specimens.

I have noticed all that is necessary for Geologists or Mineralogists to know: this place [this catalogue] does not allow to notice it.

I have few Fossils and Petrefactions, amongst them a very rare one and never before found in the Country: Celleporae echinatae similis.

This Country has some rare Mountain-Specimens.

The size is from $2: 3$ inches.

Arms and Ornaments of the Natives, whose use I shall in my journal particularize.

Collection of Wood in the shape of Books etc." [end of Summary] 
"The present Content

of my whole Collection of Natural Curiosities collected from Decbr. 1838 till Octbr. 1839 in the Colony of Swan River.

1. Plants

They are most beautifully dried and not pressed too much, therefore particularly suited for the examination of working Botanists.

I have now about 1,500 different species, including cryptogamic plants with many new Genera, partly described by me and of each species from 50 to 100 specimens, amongst them many new ones.

The etiquettes of plants contain following notices:

1. the number of each species to avoid future errors by naming of different Botanists at the same time.

2. Name of the plant. If a new genus I have described it on the spot by recent Specimens.

3. Whether a tree, shrub, half-shrub or herb

4. The hight of an Individual.

5. When a tree, I have added a part of the bark.

6. The hight of the mountains and the hills over the level of the Sea, where the plants are growing; if they are to be found only on the high or low Country.

7. Sort of the Soil.

8. Special locus natalis.

9. Neighbourhood.

10. The time, when a plant in blossom.

11. The time of maturity of the fruit, if ripe or unripe gathered.

12. Roots, if necessary.

13. Whether they occur singly or several together.

14. Numbers of the Specimens.

15. Date and year.

16. Colour of the flower.

17. Colonial and Native name, and whether used by Natives as an article of food or for any other purpose.

18. Flowers, especially of Orchideae and fruits (not yet described) in acid pyrolignous.

19. Any circumstance that struck me as remarkable or interesting about the plants.

\section{Seeds.}

I have now more than 300 different species, gathered in 1839. They are in general in their Seed-vessels in order that they may keep better. The numbers of them referre to those of the dried plants. I will send the Seeds to Great Britain in tin boxes hermetically closed.

This list is made in a hurry and I am quite sure that I have many other objects I forgot to notize.

I shall collect in this country, so unknown to Naturalists till Decbr. 1840, during which time I shall collect in the Interior and then I intend to sell my whole collection for $£ 3000$.

I have at present about 100,000 Specimens, and I am quite sure, that I shall have collected in that time about 3000 species, and if I can take of every species 80 specimens $=240,000$ Specimens.

$$
\text { L. Preiss." }
$$

Preiss appears to have exaggerated the size of his collections both in this account and the later listing in 1842; see Preiss (1842). In the latter catalogue he refers to 3-4,000 species; subsequent study revealed about 2,500 species.

The British Government did not accept Preiss's offers. There is no further information about the distribution of the two sets of botanical specimens which accompanied his letter.

On 8 January 1842, Preiss, with his collections, sailed on the "Elizabeth". Drummond had a large consignment of seeds and specimens (1st Collection) ready for despatch on the same vessel but was advised that no cargo space was available, and their departure was delayed until May of that year. [Erickson (1969) 64] 
Preiss (1842) states that his total Western Australian collections consisted of 168 minerals, rocks and fossils; $3-4,000$ species of plants (200,000 specimens); about 2,000 species of insects; 200 species of 1and-, fresh water- and sea-shells; 181 species of birds; 60 species of fish; 60-80 species of reptiles; 20 species of "Zoophyta"; 16 genera of Crustacea, and 40 species of Arachnida. Some of these figures are quoted in Stearn (1939), Whittell (1954), and Erickson (1969); the number of species of insects is incorrectly given as 200 in these references. [Whittell (1954) is a useful source of data on a number of collectors and naturalists whose interests are not only ornithological].

While working at the Herbarium of the Royal Botanic Gardens, Kew, in 1969 I borrowed material of Proteaceae, mainly Grevillea, from Trinity College, Dublin (TCD) in which there was a number of Preiss's specimens bearing labels in Preiss's script, without the collector's name, and with collection numbers different from the usual systematically ordered numbering of specimens cited in Plantae Preissianae, Lehmann, J.G.C. (ed.), 1844-1848. From my limited observations mainly restricted to Proteaceae, and other acknowledged sources, the following herbaria have specimens numbered according to Plantae Preissianae: B, BM, CAS (Dr Ferguson, pers. comm., 1970), G-DC, HBG (from my observations on Proteaceae in 1969 Preiss's collection is poorly represented here), K (Preiss numbers listed by Burbidge (1972) ), L, MEL, MO (listed by Burbidge (1972) ), NY (Meisner's herbarium), P, S, W. De Candolle (1880) 440 has a useful listing of institutions in which Preiss's collections are represented.

Miss I.H. Vegter, Utrecht University, Netherlands has kindly provided me with information about locations for Preiss's collections; the data is for a future issue of "Index Herbariorum, Part II-Collectors":- B, BR (790), C $( \pm 2000)$, CAS, CGE, ER, FI, FR, G-DC, G-DEL, GOET, HBG, K $( \pm 250)$, KIEL, L, LE $( \pm 1900)$, LD $( \pm 2500)$, MEL, P $(1536)$, PC, PR, S, W (1104 Ph.), WB, WRSL.

Preiss's specimens housed in the Königliche Herbarium, München and the Botanisches Museum, Wien, were mentioned by Martius (1850) and Kreutzer (1864) respectively (pers. comm. Dr W.D. Margadant, 1974). Some of his specimens were among collections transferred to Botanisches Museum, Berlin (B) from Naturhistorischer Verein der Rheinlande und Westfalens, Bonn (Anon. 1937, p. 149).

In Preiss's original series the specimens and seeds of a particular collection had the same number. However, after the re-ordering of specimens for 'Plantae Preissianae', the seed collections retained the original numbers [Lehmann (1848) III-IV].

For the list of identifications of Preiss's 2,700 collections see Pl. Preiss. 2: 371-429 (1848). Most of the specimens in this list are in family groups. However Preiss Nos. 2621-2644 represent several families already included earlier in the listing. In trying to locate Preiss No. 2626, the type of Grevillea hookerana (Proteaceae), I have been unsuccessful and I suspect that it and other numbers from 2621-2644 inclusive are represented by only one or very few replicates. Other botanists in Australia have also been unable to locate specimens from this series of 24 collections. Any information on their present whereabouts would be greatly appreciated.

It is possible that some other herbaria contain unrecognized specimens from this important Australian collection. Therefore data from some of the 
sheets at Dublin (TCD) are listed as a guide, and a sample of Preiss's script appears later in this paper (see p. 10).

\begin{tabular}{|c|c|c|c|}
\hline $\begin{array}{l}\text { Colle } \\
\text { and }\end{array}$ & $\begin{array}{ll}\text { n } & \text { Number } \\
\text { e } & \text { (TCD) }\end{array}$ & Correct Name & $\begin{array}{l}\text { Pl. Preiss. } \\
\text { Number }\end{array}$ \\
\hline 51 & 15.12 .1838 & Grevillea crithmifolia $\mathrm{R}, \mathrm{Br}$. & 690 \\
\hline 164 & 21. 3.1839 & Grevillea bipinnatifida $\mathrm{R} . \mathrm{Br}$. & 708 \\
\hline 181 & 5. 1.1839 & Persoonia saccata $\mathrm{R}$. Br. & 730 \\
\hline 199 & 14. 1.1839 & Grevillea vestita (Endl.) Meisn. & - \\
\hline 255 & 12. 9.1839 & Grevillea synapheae R. Br. & 702 ex parte \\
\hline 382 & 19. 5.1839 & Grevillea thelemanniana Hueg. ex Endl. & 709 \\
\hline 442 & 25.7 .1839 & Grevillea endlicherana Meisn. & 698 \\
\hline 501 & 9. 9.1839 & Conospermum triplinervium $\mathrm{R} . \mathrm{Br}$. & 743 \\
\hline 508 & 13. 9.1839 & Grevillea pilulifera (Lindl.) Druce & 715 \\
\hline 600 & 4. 9.1839 & Grevillea vestita (Endl.) Meisn. & 722 \\
\hline 855 & 16. 1.1840 & Conospermum glumaceum Lindl. & 1583 \\
\hline 875 & 17.12 .1839 & Grevillea manglesioides Meisn. & 720 \\
\hline 907 & 23.12 .1839 & Adenanthos meisneri Lehm. ex Meisn. & - \\
\hline 911 & 20.12 .1839 & Grevillea brachystylis Meisn. & 714 \\
\hline 931 & 13.12 .1839 & Grevillea diversifolia Meisn. & 697 \\
\hline
\end{tabular}

The collections span the period 15.12 .1838 to 16.1 .1840 , and the numbers are in an irregular chronological order.

The herbarium of C.M. Lemann (1806-1852; not to be confused with J.G.C. Lehmann) at Cambridge (CGE) also contains similar specimens with numbers corresponding to those on the material in Dublin, viz., 154 (error for 164?) Grevillea bipinnatifida, 442, 875 (but dated 6.12.1839), and 911. In addition there are at Cambridge (CGE) specimens corresponding to numbers $51,199,255$, and 508 .

While gathering photocopies of various examples of handwriting from the Archives at the Royal Botanic Gardens, Kew, a paragraph in a letter from Preiss to Bentham drew my attention.

Preiss's letter to Bentham sent from Hamburg and dated 8 November 1842 , reads in part:

\footnotetext{
"Having observed in the London Journal of Botany an Acacia restiacea Benth. Swan River Preiss No. 323, evidently out of my collection, I would consider it a great favour of you to inform me occasionally, how this plant comes to England, as a collection of Natural Curiosities forwarded by my Agent at Perth, Western Australia, in the beginning of 1840, has never reached Hamburg."
} 


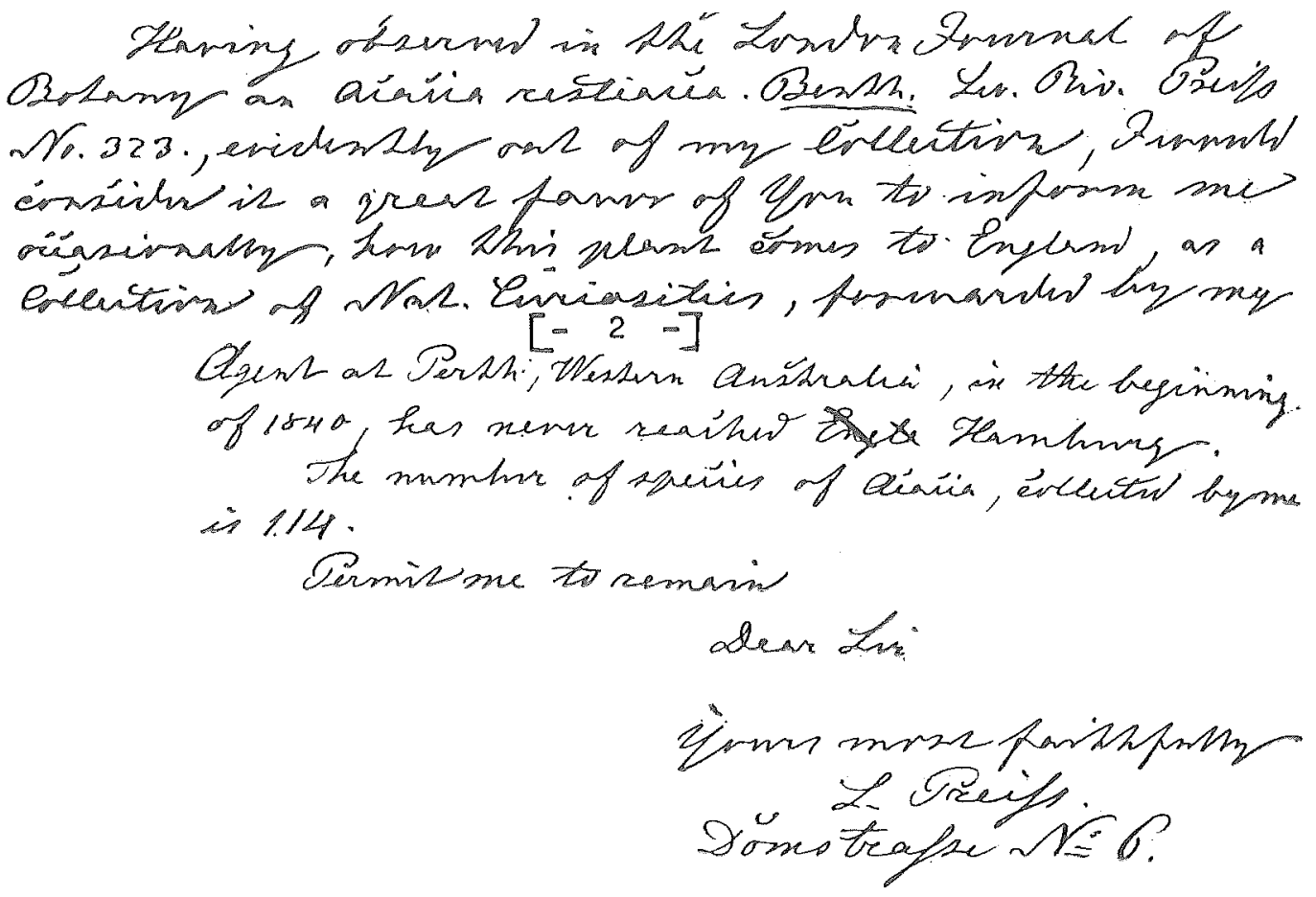

The specimen No. 323 Acacia restiacea (P1. Preiss. No. 971, collected 3.9.1839) is in the Kew herbarium but there seem to be few others of this series, the only one observed being No. 855, Conospermum glumaceum Lindl. (P1. Preiss. No. 1583, collected 16.1.1840), although no exhaustive search was made. There are, however, about 250 specimens at Kew bearing Pl. Preiss. numbers and these are listed by Burbidge (1972); the best representation, though by no means a complete one, is in the Leguminosae. According to Jackson (1901) 53, specimens from Preiss were received at Kew from 18391845 , and in 1866 .

Sir William Hooker's correspondence at Kew contains copies of letters which show how the specimens came to Dublin (TCD); duplicates of some of these collections came to Kew $(\mathrm{K})$. The purchase of two sets of specimens of vascular plants, one set for W.H. Harvey and one for Hooker, was arranged by Baron Ludwig, who was acting on Preiss's behalf.

My dear Baron,

"Cape Town. March 6th 1839.

I shall feel much obliged by your taking two shares in $\mathrm{Mr}$ Preiss's collections of Swan River plants without distinction on my account-one for myself the other for Sir W. Hooker-of course on equally favourable terms as to price with other shareholders. . . I shall probably be 18 months absent, therefore wish that all plants be for me be sent as ships offer to London, addressed care of N.B. Ward Esquire [the inventor of the very successful Wardian cases for the transport of living plants]. . . I will also subscribe to one set of insects, if in good preservation and carefully packed. But no shells, I want the insects for Joseph Hooker."

[extracted from the copy of Harvey's letter].

"Perth Feb. 1st 1840.

According to the wish of the Honorable W. H. Harvey I send you case of plants and insects... I beg leave to request you to inform Sir W. J. Hooker in Glasgow, 
(an intimate friend of his) that you have received a large collection of dried plants and insects from Swan River for the Honorable W. H. Harvey and that such species has been sent in duplicate."

[extracted from the copy of Preiss's letter to Nathaniel Ward].

The copy of the account from Preiss to Harvey, dated Feb. 1st 1840 shows: =

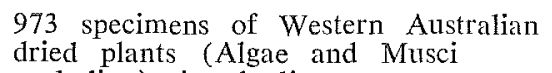

62610

Among the collections from the Harvey Herbarium acquired by Stanford University (DS), now in the possession of the California Academy of Sciences, San Francisco (CAS), is a further set of Preiss's specimens but these are numbered according to Plantae Preissianae and dated 1852, probably the year in which Harvey acquired them (pers. comm., Dr I.K. Ferguson, 1970).

The fate of the missing shipment of specimens, about which Preiss so openly expressed his suspicions, is apparently still unknown.

Preiss arrived in England in the spring of 1842 and stayed until the end of June. At one time he was in a pecuniary "situation which makes my leaving impossible" and shortly after was anxious to depart "as my expenses here increase from day to day".

William Hooker not only purchased seeds and specimens from Preiss but also introduced him to other potential buyers. Thus Preiss was provided with the means necessary to continue to Hamburg. There the general systematic arrangement of Preiss's collections was completed, and the organization of Plantae Preissianae commenced under the guidance and supervision of J.G.C. Lehmann, Professor of Botany and Director of the Hamburg Botanic Garden.

Before Plantae Preissianae was issued, Lehmann published some new names, based on these collections, in his Novarum et Minus Cognitarum Stirpium Pugillus Octavus, II Novitiae Florae Novae Hollandiae issued in April to early May 1844. Representatives of the following groups, later treated in Plantae Preissianae, were included:-

Musci (incl. Hepaticae) pp. 29-31; Cycadeaceae pp. 31-36; Droseraceae pp. 36-46; Utricularieae pp. 46-50; Cyperaceae pp. 50-56.

[In Plantae Preissianae the authorship of many of these names is not directly attributed to Lehmann; e.g., Hampe regards Gottsche as the author of Petalophyllum Nees et Gottsche ex Lehmann (Hepaticae) although Gottsche published the name about two and a half years later than Lehmann did (and, incidentally, only about seven weeks before its re-publication in Plantae Preissianae). Such practices, now contrary to our retroactive Code of Nomenclature, were perhaps not uncommon at that time.] 
A number of European botanists were invited to prepare treatments of various families [see Lehmann [ed.] 1844-1848, Praefatio]. In Bot. Zeitung (Berlin) 2: 108 (1843) a preliminary announcement advises that printing will begin next year. Meisner (1844), in a notice, dated March of that year, giving details of the title, principal authors and purchase price, states that printing has already begun and is proceeding rapidly. He lists the major contributors as:-

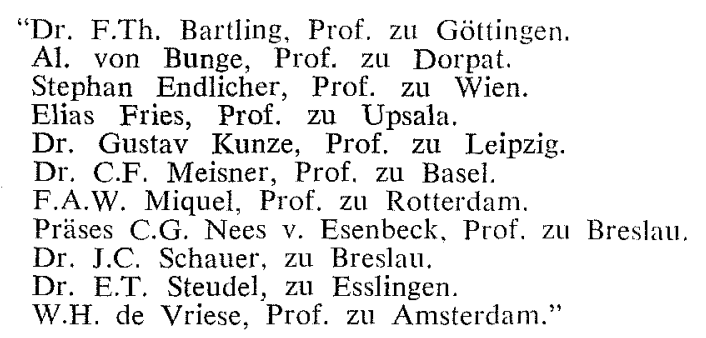

There are naturally differences in the quality of the work but much of the contemporary criticism was directed towards E.G. Steudel whose treatments of the Bütneriaceae, Polygaleae and Rhamneae were revised in the second volume of the work.

The dates of publication given here are those determined by Stafleu (1967) 263 , based on the receipt of the parts in Leipzig as recorded in Hinrich's "Börsenblatt". As Stafleu points out (1966) 62:- "These dates of receipt at Leipzig can be taken as the dates of effective publication. In a few instances the book [parts] may have been available somewhat earlier in the actual town of publication but this difference will mostly be irrevelant."

Plantae Preissianae, sive enumeratio plantarum, quas in australasia occidentali et meridionali-occidentali annis 1838-1841 collegit Ludovicus preiss. Partim ab aliis, partim a se ipso determinatas descriptas illustratas edidit [auctor]. Hamburg [1844-] 1845-1847 $[-1848], 2$ vols. Oct.

$\begin{array}{cc}\text { vol. } & \text { part } \\ 1 & 1 \\ & 2 \\ & 3 \\ 2 & 4 \\ & 1 \\ & 2-3\end{array}$

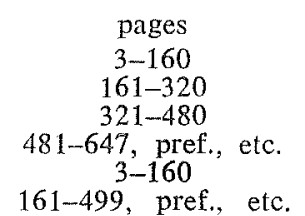
dates of receipt by Hinrichs
19-21 Sep 1844
9-11 Feb 1845
14-16 Aug 1845
$3-5$ Nov 1845
26-28 Nov 1846
3-5 Aug 1848

The following table is a guide to the contents of Plantae Preissianae; used in conjunction with the above information the dates of publication of any particular treatment can be determined. In this table some cross references are included for species now placed in other families and for names likely to be unfamiliar or rarely used in more recent times.

VOLUME I.

Praefatio

Leguminosae-Cycadeaceae

VOLUME II.

Praefatio

Typhaceae-Algae

Addimenta et Emendationes

Appendix (Rhamneae, Polygalene and Buttneriaceae)

Curae Posteriores

Index (Collection numbers)

Index Alphabeticus

\section{Pages}

V-VIII

1-647

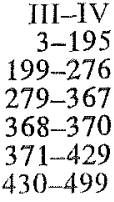




Grotp
FUNGI
ALGAE
Characeae
LICHENES
MUSCI (incl. Hepaticae)
PTERIDOPHYTA
Lycopodiaceae
Polypodiaceae
GYMNOSPERMAE
Cupressinae
Cycadeacea

\section{Author}

E. Fries

O.W. Sonder

A. Braun

E. Fries

E. Hampe

G. Kunze

G. Kunze

F.A.W. Miquel

J.G.C. Lehmann
Vohnne and pages

II. $130-140$

II. $148-195$

II. $145-148$

II. $140-145$

II. $113-130$

II. $108-109$

II. $109-113$

\section{ANGIOSPERMAE}

Aizoaceae--see Büttneriaceae I. 229-230, II. 359--361; and Mesembryanthemea

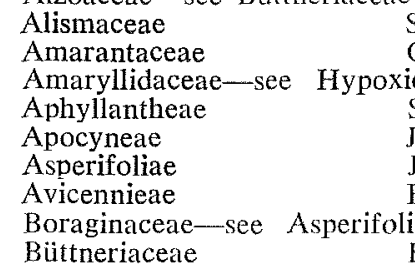

Büttneriaceae

Calectasieae

Campanulaceae

Caryophylleae

Casuarineae

Centrolepidaceae-se

Cephaloteae

Chenopodeae

Chrysobalaneae

Commelynaceae

Compositae

Convolvulaceae

",

Crassulaceae

Cruciferae

Cyperaceae

Desvauxieae

Dicrastylidacene-see

Dilleniaceae

Dioscoreae

Diosmeae

Droseraceae

Epacrideae

Euphorbiaceae

Frankeniaceae

Gentianeae

Geraniaceae

Goodeniaceae

Gramineae

Gyrostemonaceae-se

Haemodoraceae

Halorageae

Hypericineae

Hypoxideae

Irideae

Juncagina

Junceae
S.L. Endlicher C.G.D. Nees von Esenbeck ideae

S.L. Endlicher

J.G.C. Lehmann

J.G.C. Lehmann

F.A.W. Miquel

oliae

E.G. Steudel

J. Steetz

J.G.C. Lehmann

W.H. de Vriese

F.G. Bartling

F.A.W. Miquel

Desvauxieae

C.G.D. Nees von Esenbeck

C.G.D. Nees von Esenbeck

C.G.D. Nees von Esenbeck

J.G.C. Lehmann

J. Steetz

J.G.C. Lehmann

W.H. de Vriese

J.G.C. Lehmann

C.G.D. Nees von Esenbeck

A. Bunge

C.G.D. Nees von Esenbeck

C.G.D. Nees von Esenbeck

Amarantaceae

E.G. Steudel

J.G.C. Lehmann

C.G.D. Nees von Esenbeck

F.G. Bartling

J.G.C. Lehmann

O.W. Sonder

J.F. Klotzsch

J.G.C. Lehmann

C.G.D. Nees von Esenbeck

C.G.D. Nees von Esenbeck

[Lehmann, and Nees]

C.G.D. Nees von Esenbeck

W.H. de Vriese

C.G.D. Nees von Esenbeck

Phytolaccaceae

S.L. Endlicher

J.G.C. Lehmann

C.G.D. Nees von Esenbeck

C.G.D. Nees von Esenbeck

J.G.C. Lehmann

S.L. Endlicher

Alismaceae

E. Meyer
II. $53-55$

I. 626-631

II. $40-44$

I. 366

I. $347-349$, II. $238-239$

I. 353

I. $229-238$

II. $316-364$

II. 53

II. $241-244$

I. $243-245$

I. $639-643$

I. 278

1. $632-637$

I. $95-96$

II. 55

I. $417-490$

II. $244-245$

I. $345-347$

II. $237-238$

I. $277-278$

I. 257-262

II. $72-94,275$

II. $70-71$

I. 631

I. $264-276$

II. 236

II. 33

I. $165-174$, II. $226-228$

I. $249-257$, II. $235-236$

I. 296-336

I. $174-180$, II. $229-233$

II. $369-370$

I. 249

I. $363-365$

II. $239-240$

I. $161-164$

I. $400-416$

II. $95-108,275$

II. $14-29$

II. 274

I. 158-159, II. 224-226

I. 229

II. 14

II. $29-32$

II. $46-48$ 
Group

Kingiaceae

Labiatae

Laurineae

Leguminosae

Lentibula

Liliaceae

Liliaceis affine

Lineae

Lobeliaceae

Loganiaceae

, -s

Loranthacea

Malvaceae

" -see also Büttneriaceae

Author

Lehmann (p.p.), Nees (p.p.)

F.G. Bartling

C.G.D. Nees von Esenbeck

J.G.C. Lehmann

Utricularieae

S.L. Endlicher

Melanthaceae

Menyanthaceae-see

Mesembryanthemeae

Myoporineae

Myrtaceae

Najadeae

Nyctagineae

Oenothereae

Olacineae

Onagraceae-see

Orchideae

Oxalideae

Philydreae

Phytolaccaceae

Pittosporeae

Plantaginene

Polygaleae

,"

Polygoneae

Portulaceae

[Potamogetonacene]

Primulacene

Proteaceae

Ranunculaceae

Restiaceae

Rhamneae

Rosaceae

Rubiaceae

Rutaceae-see Diosmeae

Santalaceae

Sapindaceae

antheae and Melanthaceae

S.L. Endlicher

F.G. Bartling

W.H. de Vriese

C.G.D. Nees von Esenbeck

so Gentianease

$$
\text { F.A.W. Miquel }
$$

F.A.W. Miquel

J.G.C. Lehmann

J. Steetz

\section{S.L. Endlicher}

\section{Gentianeae}

J.G.C. Lehmann

F.G. Bartling

J.C. Schauer

J.G.C. Lehmann

J.G.C. Lehmann

C.G.D. Nees von Esenbeck

C.G.D. Nees von Esenbeck

F.A.W. Miquel Oenothereae

S.L. Endlicher

E.G. Steudel

J.G.C. Lehmann

J.G.C. Lehmann

A. Putterlick

J.G.C. Lehmann

C.G.D. Nees von Esenbeck

E.G. Steude1

J.G.C. Lehmann

J. Steetz

C.F. Meisner

F.A.W. Miquel

J.G.C. Lehmann

S.L. Endlicher

C.G.D. Nees von Esenbeck

C.F. Meisner

E.G. Steudel

C.G.D. Nees von Esenbeck

E.G. Steudel

S. Reissek

C.G.D. Nees von Esenbeck

F.G. Bartling

F.A.W. Miquel

J.G.C. Lehmann
C.F. Meisner

Volume and pages

II. $52-53$

I. $354-363$

I. $619-622$

I. $3-59$, II. 199-223

II. $368-369$

II. $33-39$

II. $39,274-275$

I. 161

I. $393-399$

I. $366-368$, II. 240

I. 365 , II. $239-240$

I. $279-282$

I. $238-242$

II. 235

II. $365-367$

I. $236-237$,

II. $44-45$

I. $364-365$

I. 248

I. $349-352$

I. $96-158$, II. 223-224

II. 369

II. 3-4

I. 622

I. $159-160$

I. 228

II. 4-14

I. $160-161$

II. $45-46$

I. 243

I. $189-205$

II. 233

I. $490-491$

I. $206-211$

II. 233

II. $291-315$

I. $623-626$,

I. $245-248$

II. 235

II. 273

I. $337-338$

I. $491-601$, II. $245-268$

I. $262-263$

II. $56-69$

I. $182-189$

II. $279-291$

I. 95

I. $369-370$

I. $608-619$

F.A.W. Miquel

II. 272

I. $223-228$

$\begin{array}{lc}\text { J.G.C. Lehmann } & \text { II. } 235 \\ \text { ae II. } 228 \text { [Empleturosma }=\text { Dodonaea }] & \text { II. } 236\end{array}$

Saxifrageae

Scrophularinae

J.G.C. Lehmann

F.G. Bartling

II. 236

J.G.C. Lehmann

I. $341-343$

C.G.D. Nees von Esenbeck

Solanaceae - see

Stackhousiaceae

II. 237

I. $343-345$

II. 237

I. $180-182$

Stylideae A.

Stylobasiaceae-see Chrysobalaneae

Thymelaeae

O.W. Sonder

I. $370-393$

Tremandreae

C.F. Meisner

J. Steetz

I. 601-607, II. 268-272

I. 211-223, II. 233-235 


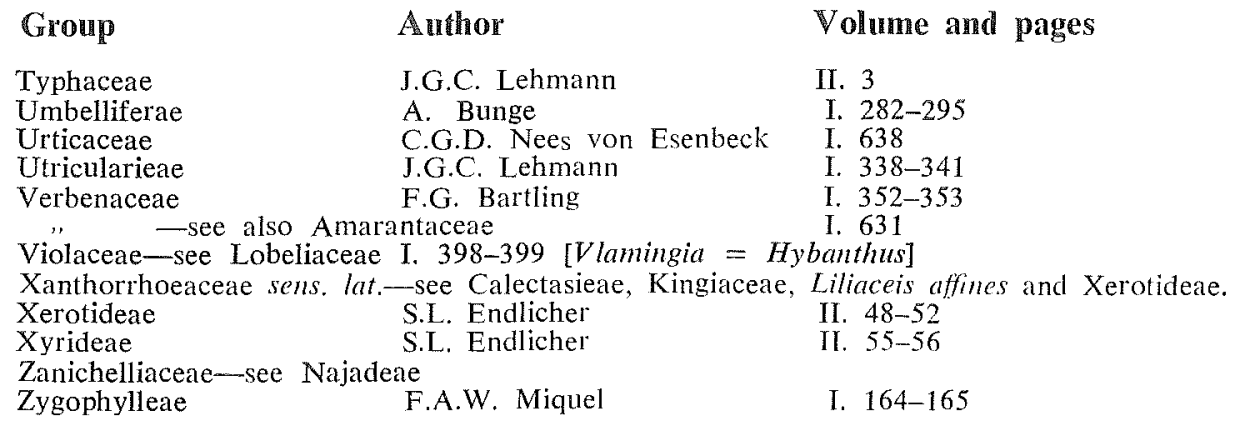

[Note that in the publication the initials of authors are those of the "Latin" equivalents, e.g. Wilhelm - Gulielmus, Gottlieb - Theophilus.]

Krempelhuber (1867) described two new species of lichens as well as mentioning taxa of this group already treated in Plantae Preissianae (pers. comm. Dr W.D. Margadant, 1974).

Preiss returned to Herzberg am Harz in 1843. Two letters, one to Sir William Hooker, the other to Robert Brown, contain some further interesting and useful information about Preiss and his collections. They are quoted here in full:-

My dear Sir,

"Herzberg am Harz

4 Octbr. 1843

According to my promise, I have the pleasure of sending You a small collection of Plants from Western- and South-Western Australia. Since the time I had the Honor to see You I was so much burried in occupation that I could not fulfil my promise sooner.

The Musci You will also receive as soon as I shall be able to send them to You.

I very much regret not having been able to collect of all species an aequal number of specimens, and those persons, who wont plants, appear to be dissatisfied not to get a whole collection of my plants. I have almost sold my plants, and I think, that those, which still remain, will also be parted with very soon. They consist of 17 Herbaria, containing: 996. 956. 920, 888. 867. 884. 836. 798. 767. 732, 728. 705. 685. 669 . 645. 618. 595 species.

The numbers accompanying the plants I beg you to retain, as they exactly will agree with those of the enumeratio, which will soon be published.

Permit me to remain

$$
\begin{aligned}
& \text { My dear Sir } \\
& \text { Yours truly } \\
& \text { L. Preiss. }
\end{aligned}
$$

Did you receive in the course of last year through Prof. Lehmann the seeds of Banksiae \& Dryandrae I promised you?

Have the Macrozamia and Xanthorhoea already got leaves?"

[Hooker Correspondence]

[The letter to Robert Brown]

"Herzber'g am Harz 9 Novbr. 1843

Dear Sir,

When visiting London on my return from Western and South-Western Australia, it was one of my chief object to have a conversation with you, but I was so unfortunate not finding you at home. Being now a little released from working, I take the opportunity to give you some information of my plants collected in those parts of Australia. The number of phanerogamic plants amounts to nearly 2,500 $\mathrm{specs}^{\mathrm{s}}$. [species] and of cryptogamic

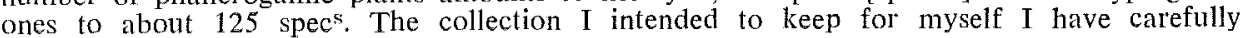


selected from the other plants, and am now inclined to dispose of it for the summe of $£ 200$. I therefore find a pleasure to offer this fine collection, including all Unica, which are very considerable, to you "the father of the Australian Flora". Several accounts of my plants by eminent German Botanists bear testimonies that the specimens are in every respect as complete as possible. They are generally accompanied by seeds and seed vessels. Each species consists frequently of 2 or 3 specimens and to each is attached the exact locus natalis. Begging, to favour me soon with an answer, I am

\author{
Dear Sir \\ Yours faithfully \\ L. Priess"
}

Brown, regrettably, could not accept the offer. At the time the British Museum Trustees allowed $£ 100$ per annum for the purchase of specimens for the Banksian Herbarium, although, on one occasion, Brown had been able to obtain a special grant of $£ 400$ for the purchase of more extensive collections [see Committee on Botanical Work (1901) 114]. This grant was probably used specifically for the purchase of collections at the auction of Aylmer Bourke Lambert's herbarium, 27-29 June 1842. [For details about the Lambert herbarium and its history see the fine study by Miller (1970).] Brown acquired several lots for the Museum, including a "magnificent herbarium" from Ruiz and Pavon's collections, Lot 103 , for $£ 270$, as well as Australasian specimens from the collections of the Forsters, Labillardière and Sieber.

Preiss's specimens would have duplicated some of Brown's own collections, as well as those being received from James Drummond. The source of Preiss's material at the British Museum (Natural History) is probably R.J. Shuttleworth's herbarium; see Carruthers (1878) 180. Preiss is not listed among the "important contributors" to the Botany Department's collections [British Museum (1904) 129 et seq.]

\title{
Preiss died at Herzberg am Harz on 21 May 1883.
}

No one since Robert Brown has made such a notable contribution in so few years as Ludwig Preiss rendered to the exploratory phase of Australian systematic botany. Plantae Preissianae, based largely on Preiss's collections, is among the foremost of the major original contributions to our knowledge of the Australian flora. In this work there are descriptions of 580 genera and 2,400 species; a large proportion of them published here for the first time.

\section{ACKNOWLEDGEMENTS}

I wish to thank Miss I.H. Vegter, Utrecht University, Netherlands, for information about the present locations for Preiss's specimens, and for her constructive criticism of an earlier manuscript.

My thanks also to Dr F.A. Stafleu for his permission to reproduce material about dates of issue of "Plantae Preissianae" from his invaluable publication 'Taxonomic Literature'.

The Librarian, Battye Library, Perth, kindly provided me with copies of Preiss's correspondence from the Colonial Secretary's Office Letters Received Volume 67, 11.10.1839, now held in the Battye Library.

Valuable assistance, for which I am most grateful, was received from Dr I.K. Ferguson (Royal Botanic Gardens, Kew), Professor D.A. Webb (University 
of Dublin), Mr A.S. George (Western Australian Herbarium, Perth), and Dr W.D. Margadant (Biohistorisch Instituut, Utrecht).

The Trustees of the British Museum (Natural History), London, and the Director, Royal Botanic Gardens, Kew, gave their kind permission for quotation and reproduction of letters held in their respective institutions.

\section{LITERATURE CITED}

Anon., 1937.-Naturhistorischer verein der Rheinlande und Westfalens.-Bonn. In Chron. Bot. 3: 148-149.

Ascherson, P.F.A. and P. Graebner, 1899-1939.-Synopsis Mitteleuropäischen Flora 4: 631-632.

Barnhart, J.H., 1965.-Biographical notes upon botanists. Boston. 3 vols.

British Museum, The Trustees of, 1904.- The history of the collections contained in the natural history departments of the British Museum. London. Vol. I in part, Botany (G. Murray assisted by J. Britten).

Burbidge, N.T., 1972.-Notes on the Preiss collection of Western Australian plants. Canberra. 11 pp. Duplicated typescript.

Calaby, J.H., 1967.-Preiss, Johann August Ludwig, in Shaw, A.G.L. and C.M.H. Clark [eds.], Australian Dictionary of Biography 2: 349-350.

Candolle, A. de, 1880.-La phytographie. Paris.

Carruthers, W., 1878.-Official report for 1877 of the Department of Botany in the British Museum. J. Bot. 16: 179-180.

Committee on Botanical Work, 1901.-Minutes of evidence taken before the departmental committee on botanical work and collections at the British Museum and at Kew with appendices and index... [London].

Diels, L., 1906.-Die vegetation der erde. VII. Die pflanzenwelt von WestAustralien südliches des wendekreises: 47-48, 52.

Erickson, R., 1969.--The Drummonds of Hawthornden. Osborne Park.

Gardner, C.A. and H.W. Bennetts, 1956.-The toxic plants of Western Australia. Perth.

Harvey, W.H., 1869.-Memoir of W.H. Harvey, M.D., F.R.S., late professor of Botany, Trinity College, Dublin. London.

Hasluck, A.M.M., 1955.-Portrait with background. A life of Georgina Molloy. Melbourne and Wellington.

Jackson, B.D., 1901.--A list of the collectors whose plants are in the herbarium of the Royal Botanic Gardens, Kew, to 31st December, 1899. Bull. Misc. Inform. 1901: 1-80.

Krempelhuber, A. von, 1867.-Geschichte und literatur der Lichenologie. Band I. München.

Kreutzer, K.J., 1864.-Das Herbar. Wien.

Lehmann, J.G.C., 1844.-Novitiae florae Novae Hollandiae. Novarum et minus cognitarum stirpium pugillus octavus. Hamburg.

Lehmann, J.G.C. [ed.], 1844-1848.-Plantae Preissianae. Hamburg. 2 vols.

Martius, K.F.P. von, 1850.-Das königliche herbarium zu München; published as a separate from Gel. Anz. 31. [fide Bot. Zeitung (Berlin) 9: 155 (1851)]

Meise, W., 1951.-Notes on the ornithological collections of Preiss in the Swan River Colony, 1838-1841. Emu 51: 148-151. 
Meisner, C.F., 1844.- Intelligentzblatt. Bot. Zeitung (Berlin) 2: 415-416.

Miller, H.S., 1970.-The herbarium of Aylmer Bourke Lambert. Notes on its acquisition, dispersal, and present whereabouts. Taxon 19: 489-553.

Moore, G.F., 1884.-Diary of ten years eventful life of an early settler in Western Australia. London.

Preiss, J.A.L., 1842.-Neueste sammlung australischer naturproducte in Hamburg. Linnaea 16: 384-388.

Smith, G.G., 1953.-Pioneer botanists of Western Australia. J. \& Proc. Western Austral. Hist. Soc. 4 (5): 59-73.

Stafleu, F.A., 1966.-F.A.W. Miquel, Netherlands botanist. Wentia vol. 16.

Stafleu, F.A., 1967.-Taxonomic literature. Utrecht and Zug.

Stearn, W.T., 1939._Lehmann's "Plantae Preissianae". J. Soc. Bibliogr. Nat. Hist. 1 (7): 203-205.

Whittell, H.M., 1954.-The literature of Australian birds. Perth. 